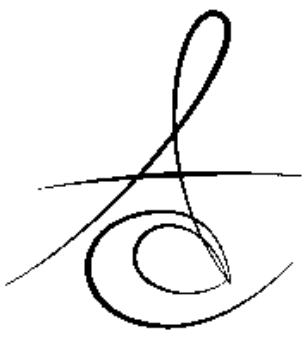

\title{
THE EVALUATION OF THE COLONIZATION AND BIOFILM FORMATION CAPACITY OF THE CANDIDA SPECIES ISOLATED FROM DENTURE WEARER PATIENTS
}

\author{
HAREKETLİ PROTEZ KULLANAN HASTALARDA KANDİDA TÜRLERİNİN \\ KOLONİZASYONUNUN VE BİYOFİLM OLUŞTURMA KAPASİTELERİNİN
}

\author{
Dr. Öğr. Üyesi Süleyman Emre MEŞELİ \\ Dr. Öğr. Üyesi Gizem ÇOLAKOĞLU*** \\ Dr. Öğr. Üyesi Esra KOÇ Ç**** $^{* *}$
}

\author{
Dr. Gonca ERKÖSE GENÇ \\ Dr. Suleyman PELIT ${ }^{* * * *}$ \\ Doç. Dr. Birsay GÜMRÜ TARÇIN ${ }^{* * * * *}$
}

Makale Kodu/Article code: 3949

Makale Gönderilme tarihi; 10.01 .2019

Kabul Tarihi: 17.05.2019

\section{ABSTRACT}

Aim: Candida species, although being a member of the oral flora, may exhibit pathological features under certain conditions. The aim of this study was to determine the distribution and biofilm production of Candida species that were isolated from denture related stomatitis (DRS) patients and to compare with healthy subjects.

Materials and Methods: The 56 non-smoker, systemically healthy, maxillary removable denture wearer subjects included in this study and diagnosed as $\mathrm{DRS}(\mathrm{N}=27)$ and healthy $(\mathrm{N}=29)$. Samples from the palatal mucosal surface of patients were collected by sterile swabs during 20 seconds. Cultivation and selective isolation of Candida species were performed on CHROMagar (CHROMagar ${ }^{\circledR}$ Candida, CHROMagar, Paris, France) at $37^{\circ} \mathrm{C}$ for 2 days. Isolated Candida species were identified with API ID $32 \mathrm{C}$ (bioMérieux ${ }^{\circledR}$, France). Biofilm formation by Candida species were determined by a visual tube method.

Results: The prevalence of the yeasts in the healthy group was found to be $37.94 \%$, while in the DRS group it was $100 \%(p<0.001)$. The isolation rate of $C$. albicans in patients with DRS significantly higher $(p<0.001)$. Biofilm formation was observed in a total of 37 oral yeast isolates, 9 isolates from healthy den- ture wearers and 28 isolates from DRS patients. The number of $C$. albicans and C. glabrata isolates showing biofilm formation ability in the DRS group was significantly higher than the healthy group $(p<0.05)$.

Conclusions: Within the limitations of this study, our results suggest that Candida species play a major role on the development of DRS. While $C$. albicans was the most isolated species in DRS, C. glabrata was as important as C. albicans on the pathogenesis of DRS.

Keywords: Biofilms, Candida, Denture stomatitis, Mycology, Oral pathology

\section{öz}

Amaç: Candida türleri, oral floranın doğal üyesi ol- makla birlikte, belirli koşullar altında patolojik özellikler sergileyebilir. Bu çalışmanın amacı, protez stomatiti (PS) olan hastalardan ve protez kullanan sağlıkı bireylerden elde edilen Candida türlerinin dağılımını ve biyofilm üretime kapasitelerini karşılaştırmaktır.

Gereç ve Yöntem: Sigara içmeyen, sistemik olarak sağlıklı, maksiller tam damak protez kullanan 56 kişi bu çalışmaya dahil edildi. Katılımcılar PS $(N=27)$ ve sağlıklı ( $N=29)$ olmak üzere gruplandırıldı. Hastaların palatal mukoza yüzeyinde 20 saniye boyunca steril swablar gezdirilerek sürüntü örnekleri elde edildi. Candida türlerinin kültivasyon ve seçici izolasyonu 2 gün boyunca $37^{\circ} \mathrm{C}$ 'de CHROMagar (CHROMagar $\AA$ Candida, CHROMagar, Paris, Fransa) besiyerinde ger- çekleştirildi. İzole edilen Candida türlerinin identifikas- yonu API ID 32 C (bioMérieux ${ }^{\circledR}$, Fransa) ile gerçekleş- tirildi. Candida türlerinin biyofilm oluşturma potansi- yelleri görsel tüp yöntemi ile saptandı.

Bulgular: Sağlıklı gruptaki mayaların prevalansı \% 37.94 iken, PS grubunda \% 100'dü $(p<0.001)$. PS'li hastalarda $C$. albicans'ın izolasyon oranı anlamlı dere- cede daha yüksekti $(p<0.001)$. Sağlıklı katılımcılardaki 9 PS katılımcılardaki 28 izolatta biyofilm oluşumu gözlendi. PS grubunda biyofilm oluşumunu gösteren $C$. albicans ve $C$. glabrata izolatlarının sayısı sağlıklı gruba göre anlamlı olarak yüksekti $(p<0.05)$.

Sonuç: Bu çalışmanın sınırları dahilinde, sonuçlarımız Candida türlerinin PS'nin gelişiminde önemli bir rol oynadığını göstermektedir. C. albicans, PS'de en sık izole edilen tür olsa da $C$. glabrata da PS'nin patoge- nezinde C. albicans kadar önemlidir.

Anahtar Kelimeler: Biyofilm, Kandida, Protez stomatitisi, Mikoloji, Oral patoloji

İstanbul Aydın Üniversitesi, Diş Hekimliği Fakültesi, Periodontoloji AD, İstanbul.

" İstanbul Üniversitesi,Tıp Fakültesi, Tıbbi Mikrobiyoloji AD, Istanbul.

*** İstanbul Aydın Üniversitesi Diş Hekimliği Fakültesi Ağız Diş Çene Hastalıkları ve Radyoloji AD,., İstanbul.

SSişli Hamidiye Etfal Eğitim ve Araştırma Hastanesi,Klinik Mikrobiyoloji Laboratuvarı, İstanbul.

İstanbul Aydın Üniversitesi Diş Hekimliği Fakültesi, Protetik Diş Tedavisi AD, İstanbul.

"Marmara Üniversitesi Diş Hekimliği Fakültesi Ağız Diş Çene Hastalıkları ve Radyoloji AD, İstanbul. 


\section{INTRODUCTION}

Denture-related stomatitis (DRS) is a common erythematous inflammatory response that is generally seen on the oral mucosa underlying removable dentures. ${ }^{1-3}$ Various factors may play role in the aetiology of DRS which can be listed as age, systemic diseases that affect immune response such as diabetes mellitus and HIV infection etc, salivary flow rate, prolonged usage of dentures, unhygienic and old dentures. $^{4-7}$ Furthermore, Candida species, as members of the flora on skin and mucosa, were shown to be as causative factors in DRS. ${ }^{8}$ Polymethyl metacrylate resin is preferred to fabricate the denture base generally. And due to porous structure of this material fungal colonization can be easier.

Although Candida albicans is the most commonly isolated yeast from the DRS patients ${ }^{9}$, nonalbicans species such as Candida glabrata, Candida tropicalis, Candida kefyr, Candida parapsilosis, Candida krusei and Candida dubliensis may be present in the oral cavity of these patients. ${ }^{1,8,10}$ Virulence factors of Candida species may play a significant role in this diversity. Phospholipase and proteinase activities are the well-known virulence factors of the Candida species. ${ }^{1,8}$ Besides these hidrolytic enzymes, Candida species could obtain the ferritine from the host due to their hemolytic potentialsand metabolize it for own homeostasis.

Another pathogenic capability of Candida species is the biofilm formation capacity. ${ }^{11}$ Biofilm is described as surface-attached microbial community and mutualistic interactions occur between the members of this community. ${ }^{12}$ Interactions among the members of a biofilm is called as "quorum sensing" and this plays a crucial role for the maintenance of nutritional chain within biofilm. Slime layer, the exterior layers of Candida cells is crucial for adherence to host surfaces and has an important role in the formation of biofilm structure. Mutualistic life form in the biofilms provides environmental protection, access to nutrients, metabolic co-operations and sharing of genetic traits to their members. The ability of the biofilm structure to reduce the success of antifungal therapies can be shown an example to this phenomenon. ${ }^{13}$ Studies showed that Candida biofilms are not innocent formations, they act like a reservoir for the infections ranging from superficial to invasive systemic candidiasis such as gastrointestinal tract infections, pneumonia and intravascular device-related infections. ${ }^{14-16}$ Candida albicans and its pathogenicity have been reported many times in literature ${ }^{1,17}$, but the effects of non-albicans species in the pathogenesis of DRS are still not fully clarified.

The objective of this study was to evaluate and compare the colonization and biofilm formation capacity of the Candida species isolated from denture wearer patients with DRS and healthy controls.

\section{MATERIALS and METHODS}

\section{Subjects and Clinical Examination}

The protocol of this cross-sectional study was approved by XXX with the reference number B.30.2.AYD.0.00.00-480.2/193. This research was conducted according to the principles outlined in the Declaration of Helsinki on experimentation involving human subjects.

The 56 maxillary removable denture wearer subjects (21 male/ 35 female) included in this study were recruited from Periodontology and Oral and Maxillofacial Radiology Departments of Faculty of Dentistry, Istanbul Aydin University. A detailed medical and dental history was obtained from all participants. Clinical parameters including number of teeth, plaque index $(\mathrm{PI})^{18}$, bleeding on probing (BoP), probing depth (PD) and clinical attachment level (CAL) were recorded at baseline. While PD was defined as the distance from the free gingival margin to the bottom of the periodontal pocket, the distance from the cementoenamel junction to the bottom of the periodontal pocket was recorded as CAL. All clinical examinations were carried out by a single examiner (S.E.M.). To achieve the intra-examiner calibration, 3 non-study subjects were selected and full mouth PD scores of them were recorded twice within 5 days. The intra-examiner correlation was calculated as $96.2 \%$ reproducibility.

The sample size was calculated on the basis of a similarly designed study. ${ }^{1}$ Assuming that a sample of 25 participants per group would provide $90 \%$ power to detect a true difference between the groups.

While 27 of these subjects were diagnosed as having Type II DRS according to Newton's classification ${ }^{1}, 29$ did not have any DRS symptoms. All

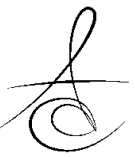


subjects were using their dentures for at least 12 months. Criteria for exclusion from the study were as follows: (a) any systemic disease (i.e. diabetes mellitus, HIV infection, anaemia) and (b) use of prolonged antibiotics or steroids that might promote oral candidiasis, (c) history of candidiasis and antifungal medications, (d) smoking, (e) any physical limitations or restrictions that might preclude normal oral hygiene procedures. Informed consent was obtained from all individual participants included in the study.

\section{Obtaining Oral Samples and Cultivating}

To ensure the standardization of sampling, all samples were carried out early in the morning at least two hours after food and beverage consuming, or any oral hygiene procedures. ${ }^{1}$ Oral swab samples were obtained from the normal palatal mucosa of healthy individuals whereas from the affected mucosa in patients with DRS by rubbing a sterile cotton swab several times along the surface for 20 seconds (Figure 1). All samples were cultivated on CHROMagar (CHROMagar ${ }^{\circledR}$ Candida, CHROMagar, Paris, France) for mycological examination (Figure 2). Following the incubation of plates at $37^{\circ} \mathrm{C}$ for 48 hours, identification of the isolates were performed by morphological procedures such as chlamydospore production on corn meal agar supplemented with $1 \%$ Tween 80 and carbohydrate assimilation pattern via commercially available API ID $32^{\circ} \mathrm{C}$ system (Biomerieux, Marcy I'Etoile, Paris, France)
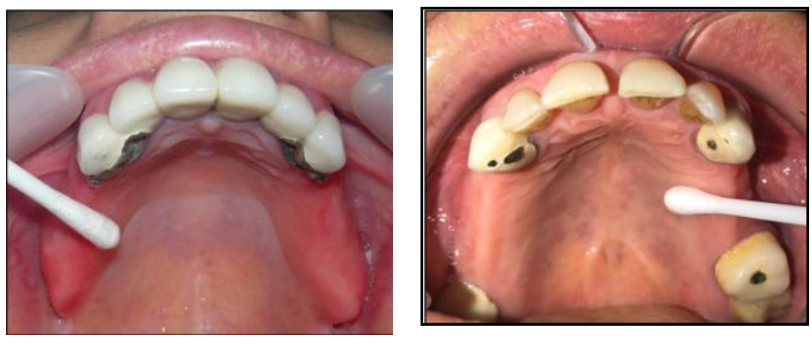

Figure 1. Obtaining of samples from the palate of patients in each group via sterile swab

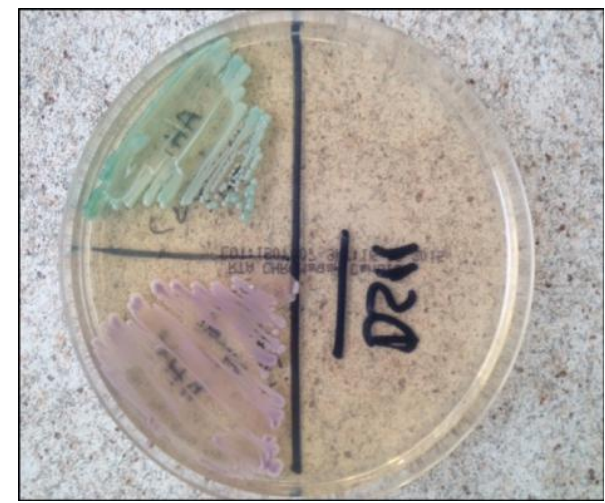

Figure 2. Candida colonies on chromogenic Candida agar

\section{Determination of the Biofilm Formation}

Visual methods were used to determine the biofilm formation (Figure 3). Isolates grown on the Sabouraud's dextrose agar plate were inoculated into a polystyrene tube contained $10 \mathrm{ml}$ of glucose supplemented with Sabouraud-dextrose broth that the final concentration was $8 \%$. Following the incubation period of $48 \mathrm{~h}$ at $35^{\circ} \mathrm{C}$, the broth was gently taken out from the tubes and the tubes were washed with distilled water for two times. Additionally, $2 \%$ safranin was applied to stain the tube for 10 min to examine the presence of the adherent layer. Biofilm formation capacity was scored as negative $(-)$, weak $(+)$, moderate $(++)$ and strong $(+++)$. As a positive control, the biofilm producer, Staphyloccoccus epidermidis ATCC35984 was used. ${ }^{19}$

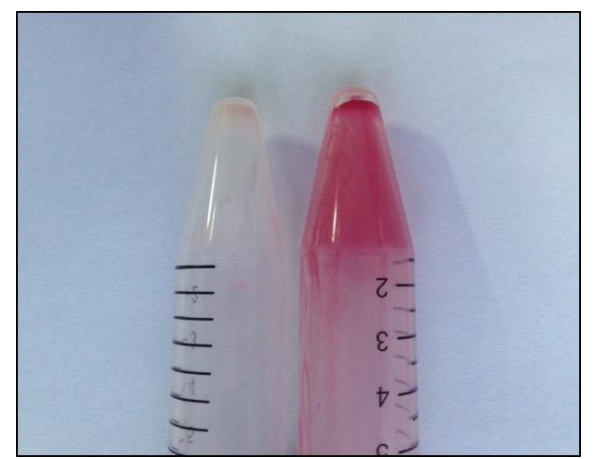

Figure 3. Biofilm formation by Candida species

\section{Statistical analyses}

The statistical analysis was performed using a computer-run statistical programme, SPSS 20 (SPSS Corporation, Chicago, USA). Mean and percentages were given for the distribution of the Candida species.

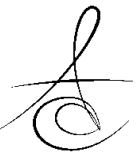


Chi-square test was used to determine the differences in biofilm formation capacity of the isolates. Results were calculated within $95 \%$ confidence intervals with the significance level set at $p<0.05$.

\section{RESULTS}

A total of 56 denture wearer subjects were included in this study and grouped according to the clinical signs of DRS as healthy $(n=29)$ or not $(n=27)$. Mean ages of healthy and DRS groups were $65.25 \pm 7.87$ and $65.13 \pm 7.74$, respectively ( $p>0.05)$. While female/male ratio of the healthy group was 2,37 , female/male ratio of DRS group was 1,23 $(p<0.05)$. The mean duration of denture use in the DRS group (10.11 \pm 6.41 years) was significantly higher

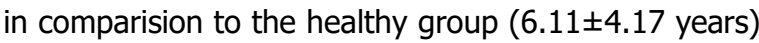
$(p<0.05)$.

Table 1 displays findings about clinical parameters at baseline. No difference was observed between the groups regarding any clinical parameters $(p>0.05)$.

Table 1. Data about clinical parameters

\begin{tabular}{|l|c|c|c|}
\hline Number of teeth & $\begin{array}{c}\text { Healthy Group } \\
(\text { Mean } \pm \text { Sd) }\end{array}$ & $\begin{array}{c}\text { DRS Group } \\
(\text { Mean } \pm \text { Sd) }\end{array}$ & $\mathbf{p}^{*}$ \\
\hline PI & $11.24 \pm 1.22$ & $10.12 \pm 1.32$ & NS \\
\hline BoP (\%) & $1.25 \pm 0.73$ & $1.54 \pm 0.88$ & NS \\
\hline PD (mm) & $54.45 \pm 10.72$ & $60.05 \pm 11.02$ & NS \\
\hline CAL(mm) & $4.25 \pm 1.94$ & $5.05 \pm 1.08$ & NS \\
\hline
\end{tabular}

Mean \pm Sd:Mean Mean \pm Standard deviation DRS: denture-related stomatitis, PI:Plaque index, BoP:Bleeding on probing, PD: Probin depth, CAL: clinical attachment level, mm:milimeter, $*$ Mann Whitney U test, NS: nonsignificant, $\mathrm{p}<0.05$

The prevalence of the yeasts in the healthy group was found to be $37.94 \%$, while in the DRS group it was $100 \%(p<0.001)$. C. albicans was the most frequently isolated species in both groups with the isolation rate of $51.85 \%$ in patients with DRS and $17.24 \%$ in the healthy group $(p<0.001)$. The other yeast species identified were $C$. glabrata, $C$. tropicalis, $C$. krusei, and $C$. dubliniensis. The distribution of the isolated Candida species were listed in Table 2. Additionally, mixed isolation rate was determined to be higher in the DRS group (22.21\%) in comparision to healthy group $(10.32 \%)$. C. albicans and $C$. glabrata were the species most frequently isolated together and isolation of these two species in DRS group was significantly higher than in the healthy group $(18.51 \%$ and $6.88 \%$, respectively) $(p<0.05)$.

Biofilm formation was observed in a total of 37 oral yeast isolates, nine isolates from healthy denture wearers and 28 isolates from denture wearers with DRS as presented on Table 3. Of the 14 isolates from the healthy group, nine $(64.2 \%)$ were biofilm positive while out of 33 isolates from the DRS group 28 $(84.8 \%)$ were biofilm positive. Biofilm formation abilities of the species are shown in Table 2. Out of the 27 tested isolates of C. albicans, 20 (74.0\%) were biofilm positive. Only $1(5.0 \%)$ of the $C$. albicans strains was strongly positive, $14(70.0 \%)$ strains were moderately positive, and five $(25.0 \%)$ strains were weakly positive. Among the 20 non-albicans Candida strains, 17 (85\%) were biofilm positive while three (15\%) did not produce biofilms. All of the C. tropicalis, C. kefyr, and C. dubliniensis isolates tested were found to be biofilm positive. Comparison between the two groups revealed that, the number of $C$. albicans isolates showing biofilm formation ability in the DRS group (16 of 19,7 of 9, respectively) was significantly higher than the number of isolates from patients in the healthy group (4 of 8$)(p<0.001)$. Moreover, similarly, the number of $C$. glabrata isolates showing biofilm formation ability in the DRS group was more pronounced than the healthy group $(p<0.05)$.

Table 2. Intragroup analyses of the distrubution of the Candida species.

\begin{tabular}{|c|c|c|c|c|c|}
\hline \multirow[t]{2}{*}{ Candida species } & \multicolumn{2}{|c|}{$\begin{array}{c}\text { Healthy } \\
\text { Group } \\
(n=29)\end{array}$} & \multicolumn{2}{|c|}{$\begin{array}{c}\text { DRS } \\
\text { Group } \\
(n=27)\end{array}$} & \multirow[t]{2}{*}{$\mathbf{p}^{*}$} \\
\hline & $\mathrm{n}$ & $\%$ & $\mathrm{n}$ & $\%$ & \\
\hline No growth & 18 & 62.06 & 0 & 0 & 0.001 \\
\hline C. albicans & 5 & 17.24 & 14 & 51.85 & 0.001 \\
\hline C. glabrata & 0 & 0 & 3 & 11.11 & 0.029 \\
\hline C. tropicalis & 1 & 3.44 & 1 & 3.70 & NS \\
\hline C. krusei & 0 & 0 & 1 & 3.70 & NS \\
\hline C. kefyr & 2 & 6.88 & 1 & 3.70 & NS \\
\hline C. dubliniensis & 0 & 0 & 1 & 3.70 & NS \\
\hline $\begin{array}{l}\text { C. albicans }+C \text {. } \\
\text { glabrata }\end{array}$ & 2 & 6.88 & 5 & 18.51 & 0.037 \\
\hline $\begin{array}{l}\text { C. albicans+C. } \\
\text { dubliniensis }\end{array}$ & 1 & 3.44 & 0 & 0 & NS \\
\hline $\begin{array}{l}\text { C. glabrata +C. } \\
\text { tropicalis }\end{array}$ & 0 & 0 & 1 & 3.70 & NS \\
\hline
\end{tabular}

$\mathrm{n}$ : Number of subjects, DRS: denture-related stomatitis, *Chisquare test, NS: nonsignificant, $p<0.05$ 
Table 3. Biofilm formation capacity of the candida species

\begin{tabular}{|c|c|c|c|c|c|}
\hline \multirow[t]{2}{*}{$\begin{array}{l}\text { Candida } \\
\text { species }\end{array}$} & \multicolumn{2}{|c|}{$\begin{array}{l}\text { Healthy Group } \\
\quad(n=14)\end{array}$} & \multicolumn{2}{|c|}{$\begin{array}{l}\text { DRS Group } \\
(n=33)\end{array}$} & \multirow[t]{2}{*}{$\mathbf{p}^{*}$} \\
\hline & $\begin{array}{l}\text { Negative } \\
\text { Isolates }\end{array}$ & $\begin{array}{c}\text { Positive } \\
\text { Isolates } \\
(+,++,+++)\end{array}$ & $\begin{array}{l}\text { Negative } \\
\text { Isolates }\end{array}$ & $\begin{array}{c}\text { Positive } \\
\text { Isolates } \\
(+,++,+++)\end{array}$ & \\
\hline C. albicans & 4 & $4(3,1,0)$ & 3 & $\begin{array}{c}16^{\mu} \\
(2,13,1)\end{array}$ & 0.001 \\
\hline C. glabrata & 1 & $1(1,0,0)$ & 2 & $7(2,5,0)$ & 0.043 \\
\hline C. tropicalis & 0 & $1(0,1,0)$ & 0 & $2(1,1,0)$ & NS \\
\hline C. krusei & 0 & 0 & 0 & $1(0,1,0)$ & NS \\
\hline C. kefyr & 0 & $2(1,1,0)$ & 0 & $1(0,1,0)$ & NS \\
\hline $\begin{array}{l}\text { C. } \\
\text { dubliniensis }\end{array}$ & 0 & $1(0,1,0)$ & 0 & $1(1,0,0)$ & NS \\
\hline
\end{tabular}

n: Number of isolated Candida species, DRS: denture-related stomatitis *Comparision between groups, Chi-square test ${ }^{\mu}$ Intragroup analyses, Chi-square test, NS: nonsignificant $p<0.05$.

\section{DISCUSSION}

Oral candidiasis emerges as a result of excessive increase of Candida species that is a member of the oral flora. ${ }^{20}$ Some predisposing factors have been reported such as old age, systemic diseases, declined salivary flow rate and denture usage. ${ }^{21,22}$ Phospholipase and proteinase production of Candida species facilitates the adherence to the mucosal surface, invasion to deep layers and causing inflammation. ${ }^{23}$ Another virulence factor of the Candida species is the biofilm formation capacity with their slime layer.

Candida species were reported to have a very high occurrence rate in the oral cavity of healthy individuals, and $C$. albicans is the most frequently isolated species. Wearing partial or complete dentures causes this rate to be higher. In several studies, the overall prevalence of Candida species was reported to be $52-55.2 \%$ and $28-89 \%$ in the oral cavities of patients without and with DRS, respectively. . $^{1,-10,24-26}$ In the present study, Candida species were isolated from the oral cavities of $37.4 \%$ of healthy people while they were isolated from all of the patients with DRS.

Due to the better adherence capacity of $C$. albicans to the mucosal surface, it has higher prevalence of isolation from the oral candidal infections. ${ }^{24,27}$ In the other studies, $C$. albicans was reported to be the most frequently isolated species with a rate of $52.9-78 \%{ }^{1,8,10,24,25}$ Similar to the other studies, the findings of the present study indicated that $C$. albicans was the most commonly isolated Candida species in both groups. ${ }^{28,30}$ Additionally, the prevalence of $C$. albicans in DRS group was higher than in the healthy group $(51.8 \%$ and 17.2 , respectively).

Although $C$. albicans is the predominant yeast in DRS, mycological ecology contributed by species diversity plays an important role in inflammation. ${ }^{25}$ In agreement with the other studies, $C$. glabrata was the most common non-albicans species in both groups. Coco et al. showed that $C$. glabrata was isolated from $31 \%$ of the DRS patients and speculated that this yeast has a synergistic relationship that causes enhanced pathogenic features with $C$. albicans. ${ }^{25}$ In the present study, $C$ glabrata appeared to co-colonize more frequently with $C$ albicans.

The biofilm formation ability of Candida species is considered to be an important virulance factor for causing infection. Biofilm formation provides these microorganisms a protection against salivary flow and other mechanical forces. The prevalence of Candida isolates effects the ability of biofilm formation. In the present study, $C$. albicans strains were $74 \%$ positive, while non-albicans strains were $85 \%$ positive for biofilm production. Yigit et al. reported that $88.0 \%$ C. albicans strains and $51.6 \%$ of the non-albicans strains were biofilm positive. ${ }^{10}$

\section{CONCLUSION}

As a conclusion, our results show that the presence of yeasts is probably linked to extensive inflammation. C. albicans was the most frequently isolated species, and $C$. glabrata was the most frequently isolated non-albicans species. Our results also indicate the biofilm production of non-albicans species as important as C. albicans.

Further investigations of the fungal virulence factors and the factors such as denture hygiene, systemic diseases and immune system deficiencies that may be involved in DRS can contribute to the development of new strategies for DRS management.

S.Emre Meşeli: ORCID ID: 0000-0002-8922-155x Gonca Erköse Genç: ORCID ID: 0000-0002-8983-9675

Gizem Çolakoğlu: ORCID ID: 0000-0002-9471-9993

Süleyman Pelit: ORCID ID: 0000-0002-0028-4264

Esra Koç: ORCID ID: 0000-0003-0435-3607

Birsay Gümrü Tarçın: ORCID ID: 0000-0002-7734-4755 


\section{REFERENCES}

1. Gumru B, Tanju K, Uygun-Can B, Ozbayrak S. Distribution and phospholipase activity of Candida species in different denture stomatitis types. Mycopathol 2006;162:389-94.

2. Uludamar A, Ozyesil AG, Ozkan Kulak Y. Clinical and microbiological efficacy of three different treatment methods in the management of denture stomatitis. Gerodontology 2011;28:104-10.

3. Yarborough A, Cooper L, Dugum I, Mendonça G, McGraw K, Stoner L. Evidence regarding the treatment of denture stomatitis. J Prosthodont 2016;25:288-301.

4. Guggenheimer J, Moore PA, Rossie K, Myers D, Mongelluzzo MB, Block HM, Weyant R, Orchard T. Insulin-dependent diabetes mellitus and oral soft tissue pathologies: II. Prevalance and characteristics of Candida and Candidal lesions. Oral Surg Oral Med Oral Pathol Oral Radiol Endod 2000;89:570-6.

5. Dorocka-Bobkowska B, Zozulinska-Ziolkiewicz D, Wierusz-Wysocka B, Hedzelek W, Szumala-Kakol A, Budzt-Jörgensen E. Candida-associated denture stomatitis in type 2 diabetes mellitus. Diabetes Res Clin Pract 2010;90:81-6.

6. Ercalik-Yalcinkaya S, Ozcan M. Association between oral mucosal lesions and hygiene habits in a population of removable prosthesis wearers. J Prosthodont 2015;24:271-8.

7. Nevalainen MJ, Narhi TO, Ainamo A. Oral mucosal lesions and oral hygiene habits in the home-living elderly. J Oral Rehabil 1997;24:332-7.

8. Marcos-Arias C, Vicente JL, Sahand IH, Eguia A, De-Juan A, Madariaga L, Aguirre JM, Eraso E, Quindos G. Isolation of Candida dubliniensis in denture stomatitis. Arch Oral Biol 2009;54:127-31.

9. Barbeau J, Seguin J, Goulet JP, de Koninck L, Avon $\mathrm{SL}$, Lalonde B, Rompre $\mathrm{P}$, Deslauriers $\mathrm{N}$. Reassessing the presence of Candida albicans in denture-related stomatitis. Oral Surg Oral Med Oral Pathol Oral Radiol Endod 2003;95:51-9.

10. Yigit $\mathrm{N}$, Aktas $\mathrm{E}$, Dagistan $\mathrm{S}$, Ayyildiz A. Investigating biofilm production, coagulase and hemolytic activity in Candida species isolated from denture stomatitis patients. Eurasian J Med 2011;43:27-32.
11. Finkel JS, Mitchell AP. Genetic control of Candida albicans biofilm development. Nat Rev Microbiol 2011;9:109-18.

12. Mohandas V, Ballal M. Distribution of Candida species in different clinical samples and their virulence. biofilm formation, proteinase and phospholipase production: a study on hospitalized patients in southern India. J Glob Infect Dis 2011;3:4-8.

13. Nett JE. Future directions for anti-biofilm therapeutics targeting Candida. Expert Rev Anti Infect Ther 2014;12:375-82.

14. Sardi JC, Scorzoni L, Bernardi T, Fusco-Almeida AM, Mendes Gianninni MJ. Candida species: current epidemiology, pathogenicity, biofilm formation, natural antifungal products and new therapeutic options. J Med Microbiol 2013;62:1024.

15. Nweze EI, Ghannoum A, Chandra J, Ghannoum MA, Mukherjee PK. Development of a 96-well catheter-based microdilution method to test antifungal susceptibility of Candida biofilms. J Antimicrob Chemother 2012;67:149-63.

16. Nikawa $H$, Egusa $H$, Makihira $S$, Okamoto $T$, Kurihara $H$, Shiba $H$, Amano $H$, Murayama $T$, Yatani $\mathrm{H}$, Hamada $\mathrm{T}$. An in vitro evaluation of the adhesion of Candida species to oral and lung tissue cells. Mycoses 2006;49:14-7.

17. Bilhan $H$, Sulun $T$, Erkose $G$, Kurt $H$, Erturan $Z$, Kutay $\mathrm{O}$, Bilgin $\mathrm{T}$. The role of Candida albicans hyphae and Lactobacillus in denture-related stomatitis. Clin Oral Invest 2009;13:363-8.

18. Silness J, Loe H. Periodontal disease in pregnancy. ii. correlation between oral hygiene and periodontal condition. Acta Odonto Scand 1964;22:121-35.

19. Gokce G, Cerikcioglu N, Yagci A. Acid proteinase, phospholipase, and biofilm production of Candida species isolated from blood cultures. Mycopathologia 2007;164:265-9.

20. Uygun-Can B, Kadir T, Gumru B. Effect of oral antiseptic agents on phospholipase and proteinase enzymes of Candida albicans. Arch Oral Biol 2016;62:20-7. 
21. Kadir T, Pisiriciler R, Akyuz S, Yarat A, Emekli N, Ipbuker A. Mycological dna cytological examination of oral candida carriage in diabetic patients and non-diabetic control subjects: through analysis of local aetiologic and systemic factors. J Oral Rehabil 2002;29:452-7.

22. Samaranayake LP, MacFarlane TW. Factors affecting the in vitro adherence of the fungal oral pathogen Candida albicans to epithelial cells of human origin. Arch Oral Biol 1982;27:869-73.

23. Ghannoum MA. Potential role of phospholipases in virulence and fungal pathogenesis. Clin Microbiol Rev 2000;13:122-43.

24. Dar-Odeh NS, Sherabi AA. Oral candidosis in patients with removable dentures. Mycoses 2003;46:187-91.

25. Coco Bj, Bagg J, Cross LJ, Jose A, Cross J, Ramage G. Mixed Candida albicans and Candida glabrata populations associated with the pathogenesis of denture stomatitis. Oral Microbiol Immunol 2008;23:377-83.

26. Gaucha LMR, Pedrosa SS, Silveira-Gomes F, Esteves RA, Marques-da-Silva $\mathrm{SH}$. Isolation of Candida spp. from denture-related stomatitis in Pará, Brazil. Braz J Microbiol 2018;49:148-51.

27. Dorocka-Bobkowska B, Konopka K, Duzgunes N. Influence of antifungal polyenes on the adhesion of Candida albicans and Candida glabrata to human epithelial cells in vitro. Arch Oral Biol 2003;48:805-14.

28. Darwazeh AM, Hammad MM, Al-Jamaei AA. The relationship between oral hygiene and oral olonization with Candida species in healthy adult subjects. Int J Dent Hyg 2010;8:128-33.

29. Moalic E, Gestalin A, Quinio D, Gest PE, Zerilli A, Le Flohic AM. The extent of oral fungal flora in 353 students and possible relationships between dental caries. Caries Res 2001;35:49-55.

30. Wang H, Wang Y, Chen J, Zhan Z, Li Y, Xu J. Oral yeast flora and its sequence diversity among a large cohort of medical students in Hainan, China. Mycopathologia 2007;164:65-72.

\section{Yazışma Adresi}

Assist. Prof. Dr. Suleyman Emre MESELI

e-mail: suleymanmeseli@aydin.edu.tr

GSM: 905304667471

Fax Number:902124116240

Office Adress: Besyol Mh. Inonu Cd. Akasya Sk. No:6, 34295, Kucukcekmece, Istanbul, Turkey. ORCID: 0000-0002-8922-155x 